\title{
Modulation of Calcium Efflux from Cultured Rat Dorsal Root Ganglion Neurons
}

\author{
John L. Werth, Yuri M. Usachev, and Stanley A. Thayer \\ Department of Pharmacology, University of Minnesota Medical School, Minneapolis, Minnesota 55455
}

The free intracellular $\mathrm{Ca}^{2+}$ concentration $\left(\left[\mathrm{Ca}^{2+}\right]_{\mathrm{i}}\right)$ is governed by the balance between the activation of $\mathrm{Ca}^{2+}$ channels and buffering and efflux processes. We tested the hypothesis that $\mathrm{Ca}^{2+}$ efflux pathways are susceptible to modulation. The whole-cell patch-clamp technique was used in combination with Indo-1-based microfluorometry to record $\mathrm{Ca}^{2+}$ current and $\left[\mathrm{Ca}^{2+}\right]_{i}$ simultaneously from single rat dorsal root ganglion (DRG) neurons grown in culture. Depolarizing test pulses $(-80$ to $0 \mathrm{mV}, 100-300 \mathrm{msec}$ ) elicited $\left[\mathrm{Ca}^{2+}\right]_{i}$ transients that recovered to basal levels by a process best-fit with a single exponential $(\tau=5.1 \pm 0.4 \mathrm{sec} ; n=14)$ and were independent of $\mathrm{Ca}^{2+}$ load (40-500 $\mathrm{pC}$ ) over this range of test pulses. $\left[\mathrm{Ca}^{2+}\right]_{i}$ transients recorded in whole-cell configuration were similar to those elicited by a brief train of action potentials in unclamped neurons. Inhibition of $\mathrm{Ca}^{2+}$ sequestration into intracellular stores with thapsigargin had no effect on the kinetics of recovery. Inhibition of plasma membrane $\mathrm{Ca}^{2+}$ ATPase (PMCA) function by including a peptide inhibitor (C28R2) in the patch pipette significantly slowed recovery to basal $\left[\mathrm{Ca}^{2+}\right]_{i}(\tau=9.9 \pm 0.8$ $\mathrm{sec} ; n=4)$. Preincubation with calmidazolium, a calmodulin antagonist, produced modest slowing of $\mathrm{Ca}^{2+}$ efflux. Phorbol dibutyrate, an activator of protein kinase $C(P K C)$, accelerated $\mathrm{Ca}^{2+}$ efflux only when the PMCA had been inhibited by C28R2. We conclude that in DRG neurons PMCAs are responsible for lowering $\left[\mathrm{Ca}^{2+}\right]_{i}$ after small $\mathrm{Ca}^{2+}$ loads and that PMCAmediated $\mathrm{Ca}^{2+}$ efflux is modulated by calmodulin- and PKCsignaling pathways.

Key words: intracellular calcium; $\mathrm{Ca}^{2+}$ ATPase; patch clamp; protein kinase $C$; Indo-1; calmodulin; dorsal root ganglion
Precise regulation of free intracellular $\mathrm{Ca}^{2+}$ concentration $\left(\left[\mathrm{Ca}^{2+}\right]_{i}\right)$ is crucial to maintain the balance between rapid $\mathrm{Ca}^{2+}$ signaling (Miller, 1988) and $\mathrm{Ca}^{2+}$-dependent toxicity (Choi, 1987; Randall and Thayer, 1992). Although a great deal is known about the regulation of $\mathrm{Ca}^{2+}$ influx and release processes in neurons (Tsien and Tsien, 1990), relatively little is known about the modulation of the processes that remove $\mathrm{Ca}^{2+}$ from the neuronal cytosol (for review, see Carafoli, 1987; Miller, 1991). Mitochondrial $\mathrm{Ca}^{2+}$ buffering shapes $\left[\mathrm{Ca}^{2+}\right]_{\mathrm{i}}$ transients caused by large $\mathrm{Ca}^{2+}$ loads (Thayer and Miller, 1990; Friel and Tsien, 1994; Werth and Thayer, 1994) and can be modulated by polyamines, $\left[\mathrm{Na}^{+}\right]_{i}$, and chronic treatment with nucleoside analogs (Jensen et al., 1989; Thayer and Miller, 1990; Werth et al., 1994). $\mathrm{Ca}^{2+}$ binding by cytosolic proteins does not appear to be modulated post-translationally, although transcription of these genes is modulated by neuronal activity (Baimbridge et al., 1992). ATPdependent $\mathrm{Ca}^{2+}$ pumping can be modulated by kinases in erythrocyles and hepatocyles (Neyses et al., 1985; Smallwood et al., 1988 ) and by calmodulin (CaM) in sensory neurons (Benham et al., 1992). $\mathrm{Ca}^{2+}$ efflux via $\mathrm{Na}^{+}-\mathrm{Ca}^{2+}$ exchange has been difficult to study in neurons, possibly because of selective localization of the exchanger to nerve terminals (Luther et al., 1992). The relative contribution of each of these processes to $\mathrm{Ca}^{2+}$ buffering in neurons is unclear.

Received July 20, 1995; revised Oct. 25, 1995; accepted Oct. 27, 1995

1his work was supported by grants from the National Institutes of Health (DA07304) and the National Science Foundation (IBN9412654). J.L.W. was supported by NIDA Training Grant T32DA07097. We thank Dr. R. P. Elde for peptide synthesis.

Correspondence should be addressed to Dr. Stanley A. Thayer, Department of Pharmacology, University of Minnesota Medical School, 3-249 Millard Hall, 435 Delaware Strcet SE, Minncapolis, MN 55455.

Copyright (C) 1996 Society for Neuroscience $0270-6474 / 96 / 161008-08 \$ 05.00 / 0$
Previous studies in dorsal root ganglion (DRG) neurons have shown that after large $\mathrm{Ca}^{2+}$ loads, $\mathrm{Ca}^{2+}$ uptake by mitochondria decreases the amplitude of the $\left[\mathrm{Ca}^{2+}\right]_{\mathrm{i}}$ transient while increasing its duration (Thayer and Miller, 1990; Werth and Thayer, 1994). Modest $\mathrm{Ca}^{2+}$ loads appear to be removed primarily by ATPdependent pumping of $\mathrm{Ca}^{2+}$ across the plasma membrane (Thayer and Miller, 1990; Benham et al., 1992).

Plasma membrane $\mathrm{Ca}^{2+}$ ATPases (PMCAs) are expressed ubiquitously in eukaryotic cells and have been studied extensively in erythrocytes (Carafoli, 1991, 1992). The PMCA is a highaffinity, low-capacity $\mathrm{Ca}^{2+}$ extrusion mechanism. CaM activates the enzyme by increasing both the affinity of the pump for $\mathrm{Ca}^{2+}$ and the rate of pumping (Smallwood et al., 1988; Carafoli, 1991). CaM acts by binding to a site near an autoinhibitory domain and changing the conformation of the pump so that this domain no longer interacts with its binding site on the pump (Carafoli, 1992). Synthetic peptides representing the autoinhibitory domain of the PMCA have been used to inhibit pump function (Enyedi et al., 1991; Enyedi and Penniston, 1993). Phosphorylation by protein kinase $\mathrm{C}$ (PKC) increases $V_{\text {max }}$ in PMCA isolated from erythrocytes (Smallwood et al., 1988). Phosphorylation by cAMPdependent protein kinase (PKA) increases the affinity of the PMCA for $\mathrm{Ca}^{2+}$ (Neyses et al., 1985). The nature of regulatory influences on PMCA function in neurons remains unknown.

We have used whole-cell patch-clamp combined with Indo-1based microfluorometry to study the kinetics of $\left[\mathrm{Ca}^{2+}\right]_{i}$ recovery from $\mathrm{Ca}^{2+}$ loads applied to cultured DRG neurons. We found that PMCAs are the dominant pathway for lowering $\left[\mathrm{Ca}^{2+}\right]_{\mathrm{i}}$ after stimuli of modest intensity. We show that this process can be accelerated by CaM and PKC. Modulation of PMCAs may be an important site for regulating $\mathrm{Ca}^{2+}$-dependent signaling processes in neurons. 


\section{MATERIALS AND METHODS}

Cell culture. Neurons from the DRG were grown in primary culture as described previously (Thayer and Miller, 1990). Briefly, the DRG from 1to 3-d-old Sprague-Dawley rats were dissected from the thoracic and lumbar regions and incubated at $37^{\circ} \mathrm{C}$ in collagenase-dispase $(0.8$ and 6.4 $\mathrm{U} / \mathrm{ml}$, respectively) for $20-30 \mathrm{~min}$. Ganglia were dissociated into single cells by trituration through a flame-constricted pipette. Cells were plated onto laminin-coated $(50 \mu \mathrm{g} / \mathrm{ml}$ laminin) glass coverslips $(25 \mathrm{~mm}$ diameter). Cells were grown in Ham's F12 media supplemented with 5\% heat-inactivated horse serum, $50 \mathrm{ng} / \mathrm{ml}$ nerve growth factor, $44 \mathrm{~mm}$ glucose, $2 \mathrm{mM}$ L-glutamine, modified Eagle's medium vitamins, and penicillin-streptomycin ( $100 \mathrm{U} / \mathrm{ml}$ and $100 \mu \mathrm{g} / \mathrm{ml}$, respectively). Cultures were maintained at $37^{\circ} \mathrm{C}$ in a humidified atmosphere of $5 \% \mathrm{CO}_{2} . \mathrm{Re}-$ cordings were made after the neurons had been in culture for 7-14 d.

Instrumentation for measuring $\left[\mathrm{C}^{2++}\right]_{i}\left[\mathrm{Ca}^{2+}\right]_{\mathrm{i}}$ was determined using a microfluorometer to monitor the $\mathrm{Ca}^{2+}$-sensitive fluorescent chelator Indo-1 (Grynkiewicz et al., 1985). For excitation of Indo-1, the light from a $75 \mathrm{~W}$ xenon arc lamp was passed through a $350(10) \mathrm{nm}$ bandpass filter (Omega Optical, Battleboro, VT). Excitation light was reflected off a dichroic mirror $(380 \mathrm{~nm})$ and through a $70 \times$ phase-contrast oil immersion objective (Leitz, numerical aperture 1.15). Emitted light was reflected sequentially off dichroic mirrors ( 440 and $516 \mathrm{~nm}$ ) through bandpass filters [405 (20) and 495 (20) $\mathrm{nm}$, respectively] to photomultiplier tubes operating in photon-counting mode (Thorn EMI, Fairfield, NJ). Cells were illuminated with transmitted light $(580 \mathrm{~nm}$ longpass) and visualized with a video camera placed after the second emission dichroic. Recordings were defined spatially with a rectangular diaphragm. The $5 \mathrm{~V}$ photomultiplier output was integrated by passing the signal through an 8-pole Bessel filter. This signal then was input into two channels of an analog-to-digital converter (Indec Systems, Sunnyvale, CA). Fieldstimulation experiments were sampled at $10 \mathrm{~Hz}$ and filtered at $2.5 \mathrm{~Hz}$. Patch-clamp experiments were sampled at $50 \mathrm{~Hz}$ and filtered at $10 \mathrm{~Hz}$.

Recording $\left.\mathrm{CCa}^{2+}\right]_{i}$ from Indo-1-loaded neurons stimulated by electricalfield stimulation. For field potential experiments, cells were loaded with Indo- 1 by incubation in $2 \mu \mathrm{M}$ Indo- $1 \mathrm{AM}$ ester for $45 \mathrm{~min}$ at $37^{\circ} \mathrm{C}$ in HEPES-buffered HBSS (HHSS), pH 7.45, containing $0.5 \%$ bovine serum albumin. III ISS was composed of the following (in mM): IILPES $20, \mathrm{NaCl}$ 137, $\mathrm{CaCl}_{2} 1.3, \mathrm{MgSO}_{4} 0.4, \mathrm{MgCl}_{2} 0.5, \mathrm{KCl} 5.4, \mathrm{KH}_{2} \mathrm{PO}_{4} 0.4, \mathrm{Na}_{2} \mathrm{HPO}_{4}$ $0.3, \mathrm{NaHCO}_{3} 3.0$, and glucose 5.6. Loaded cells were mounted in a flow-through chamber for viewing (Thayer et al., 1988b). The superfusion chamber was mounted on an inverted microscope, and cells were superfused with HHSS at a rate of $1-2 \mathrm{ml} / \mathrm{min}$ for $15 \mathrm{~min}$ before starting an experiment. A suitable cell, defined as a rounded cell body that had extended fine processes and was isolated from other cells, was localized by phase-contrast illumination. $\left[\mathrm{Ca}^{2+}\right]_{i}$ transients were elicited by evoking action potentials with field potential stimulation (Sipahimalani et al., 1992; Werth and Thayer, 1994). Field potentials were generated by passing current between two platinum electrodes via a Grass S44 electrical stimulator and a stimulus isolation unit (Quincy, MA). Trains of ten $1 \mathrm{msec}$ pulses were delivered at a rate of $10 \mathrm{~Hz}$. Stimulus voltage required to elicit action potentials varied for each individual cell. The voltage sufficient to elicit a detectable increase in $\left[\mathrm{Ca}^{2+}\right]_{i}$ from a cell was determined before beginning an experiment, and subsequent stimuli were $20 \mathrm{~V}$ over this threshold. After completion of each experiment, the microscope stage was adjusted so that no cells or debris occupied the field of view defined by the diaphragm, and then background light levels were determined (typically $<5 \%$ of cell counts). Autofluorescence from cells that had not been loaded with dye was not detectable.

Simultaneous whole-cell patch-clamp and microfuorometric recordings. Whole-cell $\mathrm{Ca}^{2+}$ current $\left(I_{\mathrm{Ca}}\right)$ was measured with a Warner PC501 amplifier, filtered by an 8-pole Bessel filter with a cut-off frequency of 200 $\mathrm{Hz}$, and collected on the computer system described for fluorescence data acquisition. Thirty second sweeps were acquired every $2 \mathrm{~min}$ at a sampling frequency of $50 \mathrm{~Hz}$ except during the test pulse, during which data were sampled at $1 \mathrm{kHz}$ to resolve $I_{\mathrm{Ca}} . I_{\mathrm{Ca}}$ was isolated from all other currents by ionic substitution. Extracellular recording solution consisted of the following (in mM): TEACl $143, \mathrm{CaCl}_{2}, 2, \mathrm{MgCl}_{2} 1$, HEPES 10, and glucose $10, \mathrm{pH} 7.4$. Cells were approached with glass recording electrodes that were heat-polished to a resistance of $1-2 \mathrm{M} \Omega$ and filled with the following solution (in $\mathrm{mm}$ ): Cs-gluconate 137, $\mathrm{MgCl}$, 1, HEPES 10, Indo-1 0.1, Mg-ATP 5, and $\mathrm{Na}_{2}$-GTP 1, pH 7.3. In some studies, drugs were introduced into the cell through the patch pipette. $I_{C \text { a }}$ was elicited by stepping from -80 to $0 \mathrm{mV}$. Background fluorescence was measured after a $G \Omega$ seal was formed but before breaking into the cell, to account for fluorescence contributed by the Indo- 1 in the pipette. The objective was focused near the middle of the cell, below the plane of the pipette. Pipette solution was made with deionized nanopure $\mathrm{H}_{2} \mathrm{O}$ (Barnstead, Dubuque, IA) and had a final $\left[\mathrm{Ca}^{2+}\right]$ of $<100 \mathrm{~nm}$ as indicated by ratio measurement of a drop placed on the stage of the microfluorumeter. Because no calcium buffer other than Indo-1 was included in the patch pipette, 2 min separated every depolarization to allow the cells sufficient time to lower $\left[\mathrm{Ca}^{2+}\right]_{\mathrm{i}}$.

Calibration. Fluorescence records were corrected for background offline, and ratios were calculated. Ratios were converted to $\left[\mathrm{Ca}^{2+}\right]_{i}$ by the equation $\left[\mathrm{Ca}^{2+}\right]_{\mathrm{i}}=K_{\mathrm{D}} \beta\left(R-R_{\min }\right) /\left(R_{\max }-R\right)$, where $R$ is the $405 / 495$ $\mathrm{nm}$ fluorescence ratio (Grynkiewicz et al., 1985). The dissociation constant used for Indo-1 was $250 \mathrm{~nm}$, and $\beta$ was the ratio of the emitted fluorescence at $495 \mathrm{~nm}$ in the absence and presence of calcium. $R_{\min }$, $R_{\max }$, and $\beta$ were determined in ionomycin-treated cells in $\mathrm{Ca}^{2+}$-free buffer ( $1 \mathrm{~mm}$ EGTA) and saturating $\mathrm{Ca}^{2+}\left(10 \mathrm{mM} \mathrm{Ca}{ }^{2+}\right)$. The system was recalibrated after any adjustments. Values of $R_{\min 1}, R_{\max }$, and $\beta$ ranged from 0.94 to $1.01,8.4$ to 10.05 , and 2.9 to 3.8 , respectively.

Data are presented as mean \pm SEM. Data analysis was performed using either Student's $t$ test or ANOVA with the Bonferroni post hoc test to determine significance.

Reagents. C28R2 and G25 were synthesized in the laboratory of Dr. R. P. Elde using an Applied Biosystems Synergy system (Foster City, CA). The sequences for C28R2 and G25 are LRRGQILWFRGLNRIQTQIRVVKAFRSS and KKAVKVPKKEKSVLQGKLTRLAVQI, respectively. The peptides were amidated at the $C$ terminus. They were purified by $\mathrm{C} 18$ reverse-phase HPLC in $0.1 \%$ trifluoroacetic acid and cluted with an $\mathrm{H}_{2} \mathrm{O}$-acetonitrile gradient. Solvents were removed by lyophilization. H-7 was purchased from Research Biochemicals (Natick, MA), and Indo-I was purchased from Molecular Probes (Eugene, OR). All other reagents were purchased from Sigma (St. Louis, MO).

\section{RESULTS}

\section{Simultaneous measurement of $\left[\mathrm{Ca}^{2+}\right]_{\mathrm{i}}$ and $I_{\mathrm{Ca}}$ enables recording of $\left[\mathrm{Ca}^{2+}\right]_{i}$ transients from quantitative $\mathrm{Ca}^{2+}$ loads}

$\left[\mathrm{Ca}^{2+}\right]_{\mathrm{i}}$ transients were recorded in combination with $I_{\mathrm{Ca}}$ in the whole-cell patch-clamp configuration of (Fig. $1 A$ ). This recording technique allowed the application of $\mathrm{Ca}^{2+}$ loads that were brief, quantifiable, and reproducible. $I_{\mathrm{Ca}}$ was evoked by $100-300 \mathrm{msec}$ depolarizing test pulses to $0 \mathrm{mV}$ from a holding potential of -80 $\mathrm{mV} . \mathrm{Ca}^{2+}$ influx was quantified by calculating the time integral of $I_{\mathrm{Ca}}\left(\int I_{\mathrm{Ca}}\right)$ during the test pulse. By increasing the duration of the test pulse, we attempted to apply consistent $\mathrm{Ca}^{2+}$ loads despite current rundown (see Fig. 1A, inset). The stimulus was brief compared with the duration of the recovery, so the increase in test pulse duration did not affect recovery kinetics (Thayer and Miller, 1990). Recovery from the modest $\mathrm{Ca}^{2+}$ loads applied by this method was best-fit by a single-exponential equation with a time constant of $5.1 \pm 0.4 \mathrm{sec}(n=14)$, which is in good agreement with previous reports (Thayer and Miller, 1990; Benham et al., 1992). $\mathrm{Ca}^{2+}$ loads for the expcriments described in this report ranged from 40 to $500 \mathrm{pC}$ corresponding to $0.2-2.6 \mathrm{fmol}$ of $\mathrm{Ca}^{2+}$. Despite this large range, the recovery kinetics for the $\left[\mathrm{Ca}^{2+}\right]_{\mathrm{i}}$ transients was very reproducible, with $\tau$ ranging from 3 to $7 \mathrm{sec}$. In Figure $1 B$, data from five cells, representative of the range of values for $\int I_{\mathrm{Ca}}$ and $\tau$ observed in control recordings $(n=14)$, show that for the modest $\mathrm{Ca}^{2+}$ loads used in this study, $\tau$ was not influenced significantly by the size of the $\mathrm{Ca}^{2}$ load. Cells in which $\int I_{\mathrm{Ca}}$ varied and others in which $\int I_{\mathrm{Ca}}$ was relatively constant are included in this figure. Large $\mathrm{Ca}^{2+}$ loads will recruit additional buffering processes (Ahmed and Connor, 1988; Werth and Thayer, 1994), but in these studies we avoided application of such large $\mathrm{Ca}^{2+}$ loads. In patch-clamped neurons, we observed a slight slowing of recovery to basal $\left[\mathrm{Ca}^{2+}\right]_{i}$ that developed with time after breaking into the whole-cell mode. Therefore, only data collected within $15 \mathrm{~min}$ of break-in were used in these studies. 

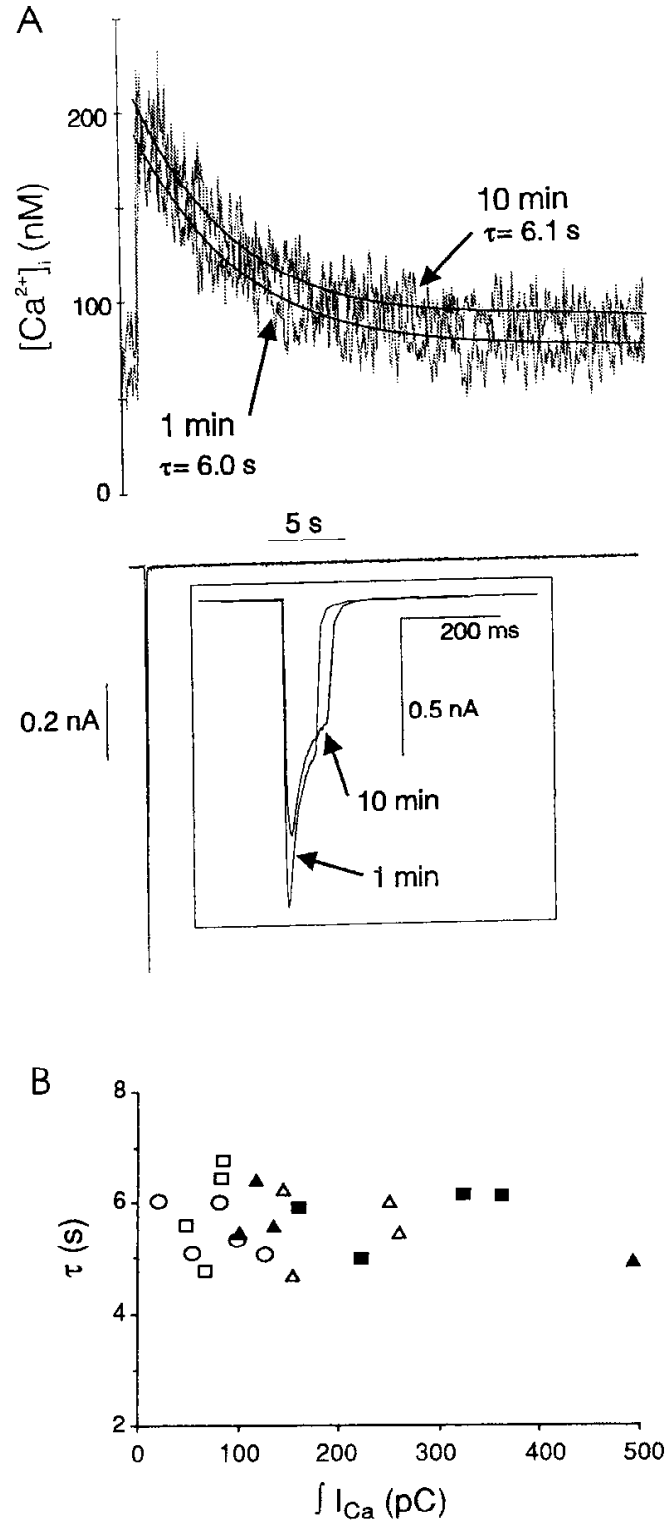

Figure 1. A, Small quantitative $\mathrm{Ca}^{2+}$ loads elicited by whole-cell voltage clamp produce $\left[\mathrm{Ca}^{2+}\right]_{i}$ transients that recover by a monoexponential process. A DRG neuron was voltage-clamped using the whole-cell configuration of the patch clamp. Traces recorded 1 and $10 \mathrm{~min}$ after break-in to the whole-cell mode are overlaid. The duration of the test pulse $(-80$ to $0 \mathrm{mV}$ ) was increased from 100 to $120 \mathrm{msec}$ to maintain comparable $\mathrm{Ca}^{2+}$ loads despite rundown in $I_{\mathrm{Ca}} . \int I_{\mathrm{Ca}}$ was calculated by integrating the current trace and was $62 \mathrm{pC}$ at $1 \mathrm{~min}$ and $57 \mathrm{pC}$ at $10 \mathrm{~min}$. The recovery to basal $\left[\mathrm{Ca}^{2+}\right]_{i}$ was fit with a single exponential (solid line), and the time constants are shown. The inset shows the current trace on an expanded time scale. $B$, The $\left[\mathrm{Ca}^{2+}\right]_{i}$ transient recovery kinetics is independent of $\mathrm{Ca}^{2+}$ load. The relationship between $\int I_{\mathrm{Ca}}$ and $\tau$ is shown for five neurons. Each cell is represented by a unique symbol. Data represent the range of $\mathrm{Ca}^{2+}$ loads and $\tau$ for the control cells included in this study $(n=14) . I_{\mathrm{Ca}}$ was varied in some cells by changing the duration of the test pulse.

\section{$\left[\mathrm{Ca}^{2+}\right]_{\mathrm{i}}$ transients evoked in whole-cell mode are comparable with those evoked by action potentials in unclamped neurons}

The kinetics of recovery to basal $\left[\mathrm{Ca}^{2+}\right]_{\mathrm{i}}$ levels was similar in the whole-cell patch-clamp configuration and in intact neurons stimulated by electrical field stimulation (Fig. 2). Field stimulation (1 sec, $10 \mathrm{~Hz}$ ) elicited action potentials (Sipahimalani et al., 1992;
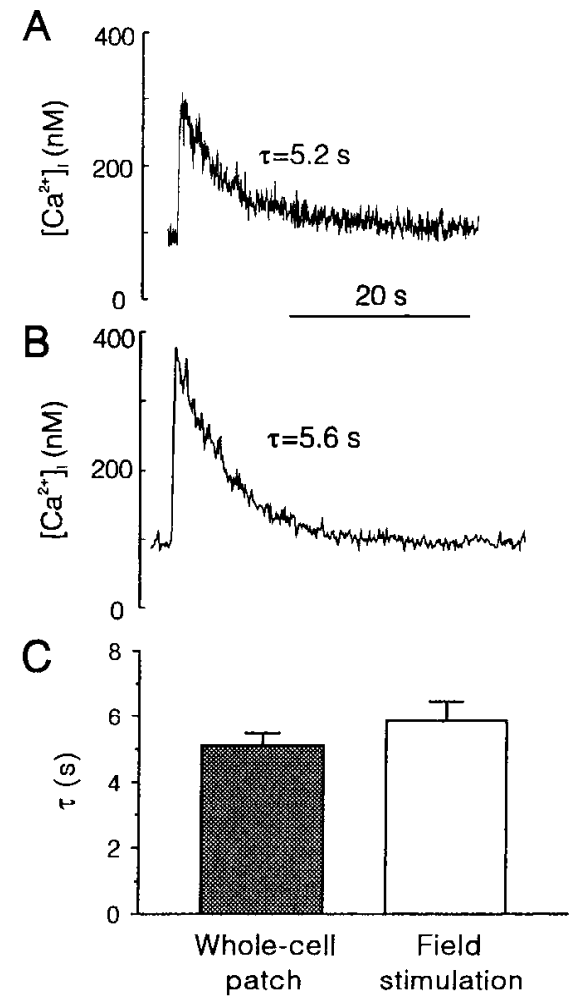

Figure 2. Recovery to basal $\left[\mathrm{Ca}^{2+}\right]_{\mathbf{i}}$ is similar in patch-clamped and intact neurons. $A$, $\left[\mathrm{Ca}^{2+}\right]_{\mathrm{i}}$ transient elicited by depolarization $(-80$ to $0 \mathrm{mV}, 100$ msec) in whole-cell mode. $B,\left[\mathrm{Ca}^{2+}\right]_{i}$ transient elicited by field stimulation. The Indo-1-loaded cell was stimulated by ten 1 msec pulses delivered at 10 Hz. $C$, Data (mean $\pm \mathrm{SEM}$ ) from 5 intact neurons and 14 patch-clamped neurons; $p>0.3$, Student's $t$ test.

Werth and Thayer, 1994); the $\tau$ describing the recovery phase of the resulting $\left[\mathrm{Ca}^{2+}\right]_{i}$ transient was $5.9 \pm 0.6 \mathrm{sec}(n=5)$. Thus, the $\mathrm{Ca}^{2+}$ loads used in these patch-clamp studies are comparable with a low-intensity stimulus in these cells that may fire at $50 \mathrm{~Hz}$ in vivo (Belmonte and Gallego, 1983). Recovery kinetics in the whole-cell mode was comparable with that observed in intact neurons $(p>$ 0.3 , field-stimulated vs patch-clamped cells), indicating that the recovery process described here was not affected significantly by whole-cell dialysis. Furthermore, tetraethylammonium ${ }^{+}$was substituted for $\mathrm{Na}^{+}$in the extracellular solution for patch-clamp recordings, which is consistent with previous reports indicating that $\mathrm{Na}^{+}-\mathrm{Ca}^{2+}$ exchange plays only a minor role in lowering $\left[\mathrm{Ca}^{2+}\right]_{i}$ in the soma of cultured neurons (Nohmi and Kuba, 1984; Benham et al., 1992; Werth and Thayer, 1994).

\section{Small $\mathrm{Ca}^{2+}$ loads are not buffered by sequestration into intracellular stores}

Previous reports indicate that in DRG neurons, ATP-dependent $\mathrm{Ca}^{2+}$ pumps are responsible for lowering $\left[\mathrm{Ca}^{2+}\right]_{i}$ (Benham et al., 1992). To determine whether sequestration into intracellular $\mathrm{Ca}^{2+}$ stores contributed to decreasing $\left[\mathrm{Ca}^{2+}\right]_{i}$ after a depolarization-induced $\mathrm{Ca}^{2+}$ load, we used thapsigargin, a selective inhihitor of sarco- and endoplasmic reticular $\mathrm{Ca}^{2+}$ ATPases (SERCAs), to determine the contribution of these pumps to recovery kinetics. Thapsigargin is irreversible and potent, with a half-maximal inhibitory potency of 10-20 nM (Thomas and Hanley, 1994). In previous studies using the same continually perfused 
A
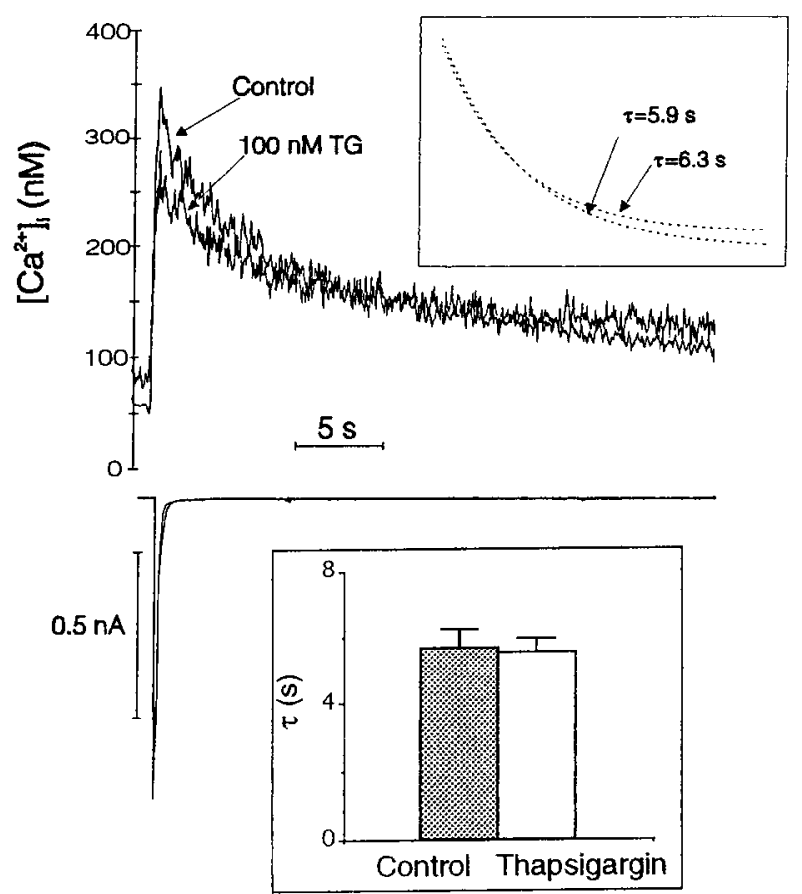

Figure 3. Small $\mathrm{Ca}^{2+}$ loads are not buffered by sequestration into intracellular stores. $\left[\mathrm{Ca}^{2+}\right]_{\mathrm{i}}$ and $I_{\mathrm{Ca}}$ are shown for a representative neuron before and after the addition of $100 \mathrm{~nm}$ thapsigargin to the superfusate. Top inset, Exponential curves fitted to the $\left[\mathrm{Ca}^{2+}\right]_{\mathrm{i}}$ data. Bottom inset, Mean $( \pm$ SEM) data from four neurons before and after $100 \mathrm{nM}$ thapsigargin was applied in the superfusate.

chamber used here, we have found complete inhibition of $\mathrm{Ca}^{2+}$ accumulation by intracellular $\mathrm{Ca}^{2+}$ stores at a concentration of 3 nм (Lo and Thayer, 1993). As shown in Figure 3, 100 nм thapsigargin applied via bath did not affect the kinetics of recovery to basal $\left[\mathrm{Ca}^{2+}\right]_{\mathrm{i}}(n=4)$. We next considered the possibility that PMCAs mediated the recovery.

\section{PMCAs buffer small $\mathrm{Ca}^{2+}$ loads}

Enyedi et al. (1991) have described a peptide inhibitor of PMCAs, $\mathrm{C} 28 \mathrm{R} 2$, that represents the CaM-binding domain of the pump. CaM activates the PMCA by binding to a site near the $\mathrm{C}$ terminus, preventing the tonic autoinhibition caused when this region of the pump binds to an inhibitory site. CaM increases both the affinity for $\mathrm{Ca}^{2+}$ and the rate of pumping (Enyedi et al., 1991; Carafoli, 1992). We included this 28-amino-acid peptide in the patch pipette to test the hypothesis that plasma membrane $\mathrm{Ca}^{2+}$ pumps are responsible for lowering $\left[\mathrm{Ca}^{2+}\right]_{i}$ after modest stimulation. To control for potential nonspecific effects of C28R2, we tested another basic peptide for effects on depolarization-induced $\left[\mathrm{Ca}^{2+}\right]_{\mathrm{i}}$ transients. Peptide $\mathrm{G} 25$ represents residues $339-363$ of the sequence of the human PMCA4 isoform and, like C28R2, has a net charge of +7 . However, in contrast to C28R2, G25 does not affect PMCA function (Enyedi et al., 1991). We observed a marked slowing of recovery to basal $\left[\mathrm{Ca}^{2+}\right]_{\mathrm{i}}$ when $10 \mu \mathrm{M}$ C28R2 was included in the pipette (Fig. $4 A$ ). This effect developed over time after establishment of the whole-cell configuration (Fig. $4 B$ ). Twelve minutes after break-in, mean $\int I_{\mathrm{Ca}}$ values for control $(n=$ 14), C28R2-treated ( $n=4)$, and G25-treated ( $n=5)$ cells were
$108 \pm 15,91 \pm 17$, and $106 \pm 38 \mathrm{pC}$, respectively; $\tau$ values were $5.1 \pm 0.4,9.9 \pm 0.8$, and $4.4 \pm 0.5 \mathrm{sec}$, respectively. Including 10 $\mu \mathrm{M}$ C28R2 in the patch pipette significantly slowed the recovery to basal $\left[\mathrm{Ca}^{2+}\right]_{i}(p<0.001$, one-way ANOVA, Bonferroni post hoc test). In contrast, G25 did not effect the recovery kinetics of depolarization-induced $\left[\mathrm{Ca}^{2+}\right]_{\mathrm{i}}$ transients significantly compared with control recordings ( $p>0.1$, one-way ANOVA; $n=5$ ). When C28R2 was in the pipette, recovery was often incomplete, causing increased $\left[\mathrm{Ca}^{2+}\right]_{i}$ at the beginning of subsequent sweeps (Fig. $4 C$ ). Basal $\left[\mathrm{Ca}^{2+}\right]_{i}$ remained relatively constant in control and $\mathrm{G} 25$ treated cells, and $12 \mathrm{~min}$ after break-in was $88 \pm 10 \mathrm{nM}(n=14)$ and $96 \pm 9 \mathrm{~nm}(n=5)$, respectively, versus $210 \pm 34 \mathrm{nм}(n=4)$ in neurons in which C28R2 was included in the patch pipette $(p<$ 0.01 , one-way ANOVA, Bonferroni post hoc test). This rise in resting $\left[\mathrm{Ca}^{2+}\right]_{\mathrm{i}}$ may account for the difficulty we encountered in producing recordings of long duration when C28R2 was included in the pipette. Cells that were patch-clamped with C28R2 in the pipette but were not stimulated maintained normal resting $\left[\mathrm{Ca}^{2+}\right]_{i}$. We conclude that the inhibition produced by $\mathrm{C} 28 \mathrm{R} 2$ is specific, and we suggest that PMCA-mediated $\mathrm{Ca}^{2+}$ efflux is the dominant process for lowering $\left[\mathrm{Ca}^{2+}\right]_{\mathrm{i}}$ after small $\mathrm{Ca}^{2+}$ loads.

\section{Modulation of PMCA-mediated $\mathrm{Ca}^{2+}$ efflux by $\mathrm{CaM}$}

C28R2 prevents CaM from activating the PMCA (Enyedi et al., 1991). C28R2 slowed $\mathrm{Ca}^{2+}$ efflux, which suggests that $\mathrm{CaM}$ is activating the PMCA in this preparation. To determine whether increasing the concentration of $\mathrm{CaM}$ would speed $\mathrm{Ca}^{2+}$ extrusion, we included $1 \mu \mathrm{M} \mathrm{CaM}$ in the pipette solution. $\mathrm{CaM}$ had no significant effect on $\tau$, which suggests that the pump already was fully activated by CaM (Fig. $5 ; n=4$ ). We explored this possibility by attempting to inhibit pump function with the $\mathrm{CaM}$ antagonist calmidazolium. Calmidazolium $(20 \mu \mathrm{M})$ applied in the superfusate for up to $12 \mathrm{~min}$ or in the pipette solution did not affect $\tau$ significantly [Fig. 5, Calmid (acute); $n=4$ ]. However, pretreatment with calmidazolium for $20-35 \mathrm{~min}$ before initiating a recording slowed recovery $(\tau=7.7 \pm 0.3 \mathrm{sec}, p<0.01$ vs control; $n$ $=5$ ). The modest effects of CaM and calmidazolium were surprising in light of the marked effect of the peptide C28R2. However, PMCA splice variants differ in their CaM-binding domains, with some exhibiting weaker autoinhibition of the pump than others (Enyedi et al., 1991). Alternatively, CaM may dissociate from the pump very slowly, requiring prolonged exposure to $\mathrm{CaM}$ antagonists to produce a robust inhibition.

\section{Modulation of PMCA-mediated $\mathrm{Ca}^{2+}$ efflux by kinases}

PMCA cDNA consensus sequences contain a number of potential modulatory sites, including PKA and PKC phosphorylation sites (Carafoli, 1992). To characterize the regulation of PMCAmediated $\mathrm{Ca}^{2+}$ efflux in DRG neurons further, the possibility that kinases regulate PMCAs was investigated. Phosphorylation of the pump protein by PKA has been reported to increase the affinity of the ATPase for $\mathrm{Ca}^{2+}$ (Neyses et al., 1985). A membranepermeant activator of cyclic nucleotide-dependent protein kinases, CPT-cAMP $(50 \mu \mathrm{M})$, failed to change the kinetics of $\left[\mathrm{Ca}^{2+}\right]_{\mathrm{i}}$ transients $(n=4)$. CPT-cAMP increased peak $I_{\mathrm{Ca}}$ in three of five neurons (mean increase, 17.4\%). PKC has been shown to stimulate the PMCA by increasing $V_{\max }$ (Smallwood et al., 1988). However, $100 \mathrm{~nm}$ phorbol dibutyrate (PDBU), an activator of $\mathrm{PKC}$, did not alter recovery to basal $\left[\mathrm{Ca}^{2+}\right]_{\mathbf{i}}(n=4)$. PDBU did increase basal $\left[\mathrm{Ca}^{2+}\right]_{\mathrm{i}}$ from $87 \pm 8$ to $128 \pm 9 \mathrm{~nm}(p<0.01)$. Furthermore, the broad-spectrum kinase inhibitor $\mathrm{H}-7$ did not affect the kinetics of $\left[\mathrm{Ca}^{2+}\right]_{\mathrm{i}}$ transients $(n=4)$. Thus, we detect no 
Figure 4. PMCAs mediate the decrease in $\left[\mathrm{Ca}^{2+}\right]_{\mathrm{i}}$ after small $\mathrm{Ca}^{2+}$ loads. $A$, Representative traces recorded 1 and $12 \mathrm{~min}$ after break-in to the whole-cell mode with $10 \mu \mathrm{M}$ $\mathrm{C} 28 \mathrm{R} 2$ in the patch pipette are overlaid. The test pulse duration was increased to compensate for rundown in $I_{\mathrm{Ca}}(1 \mathrm{~min}, 100 \mathrm{msec}, 81$ pC; $12 \mathrm{~min}, 120 \mathrm{msec}, 98 \mathrm{pC}$ ). $B$, Mean $\tau$ $( \pm$ SEM) increased over time after break-in with C28R2 in the pipette. $C$, Mean basal $\left[\mathrm{Ca}^{2+}\right]_{i}( \pm$ SEM $)$, measured during the $1 \mathrm{sec}$ before the test pulse, increased over time with C28R2 in the pipette. C28R2 $(n=4-8$ at each time point) versus control $(n=14)$, one-way ANOVA, Bonferroni post hoc test $\left({ }^{*} p<0.05 ;{ }^{* *} p<0.01 ;{ }^{* *} p<0.001\right)$.
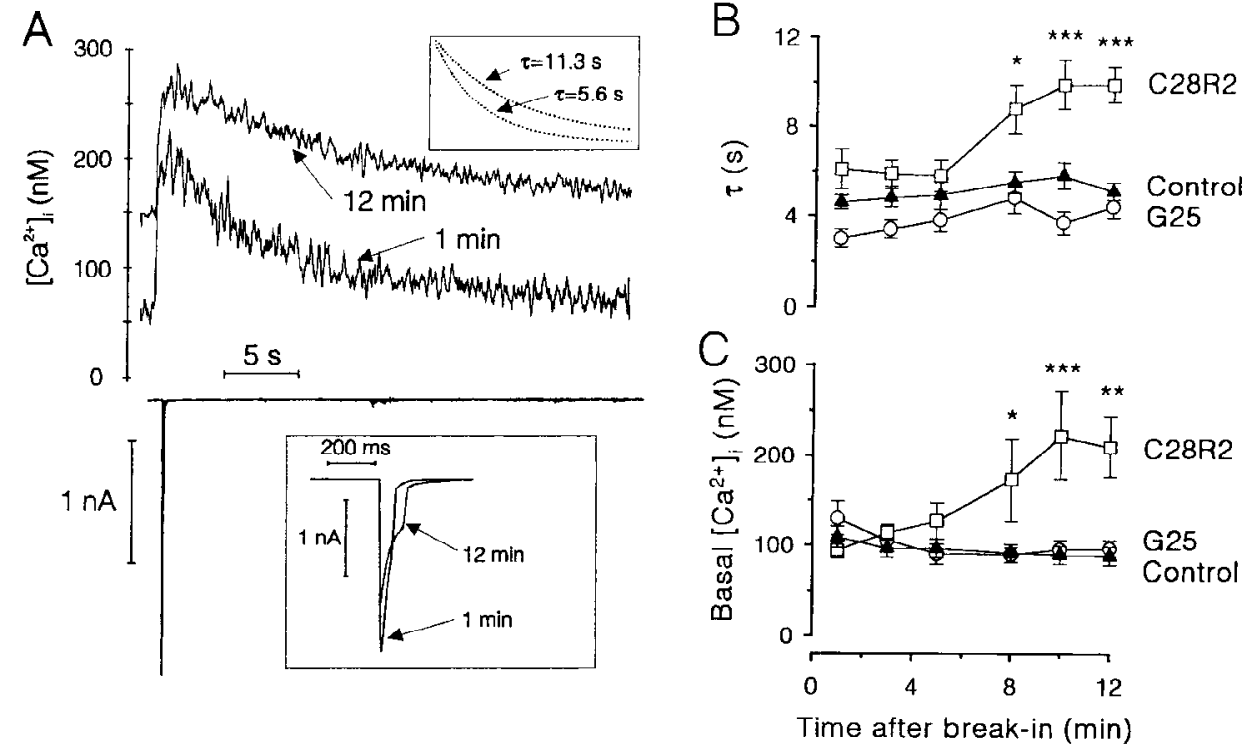

effect of kinases in PMCA-mediated $\mathrm{Ca}^{2+}$ efflux under control conditions.

We reasoned that the PMCA may be activated maximally under our experimental conditions, concealing any further enhancement of PMCA function by phosphorylation. To test this possibility, we applied kinase activators to neurons that had been dialyzed via the patch pipette with the PMCA-inhibitory peptide C28R2; $50 \mu \mathrm{M}$ CPT-cAMP did not affect the kinetics of $\left[\mathrm{Ca}^{2+}\right]_{i}$ transients, and C28R2 still slowed $\mathrm{Ca}^{2+}$ extrusion to the same extent (Fig. $6 A ; n$ $=5$ ). However, $100 \mathrm{~nm}$ PDBU blocked the slowing of recovery to basal $\left[\mathrm{Ca}^{2+}\right]_{i}$ normally seen when $\mathrm{C} 28 \mathrm{R} 2$ was included in the pipette. Neurons treated with PDBU and C28R2 exhibited smaller $\tau$ than neurons treated with C28R2 alone (Fig. 6B). This difference was significant at 10 and $12 \mathrm{~min}$ after break-in $(p<$ 0.05 , one-way ANOVA; $n=4)$. C28R2 and PDBU each caused an increase in basal $\left[\mathrm{Ca}^{2+}\right]_{\text {. }}$. Neurons exposed to both C28R2 and PDBU exhibited a rise in basal $\left[\mathrm{Ca}^{2+}\right]_{i}$ that was similar to that caused by C28R2 alone $(210 \pm 34 \mathrm{~nm}$ for C28R2, $n=4 ; 237 \pm 56$ for C28R2 and PDBU, $n=4$ ), which suggests that treatment with

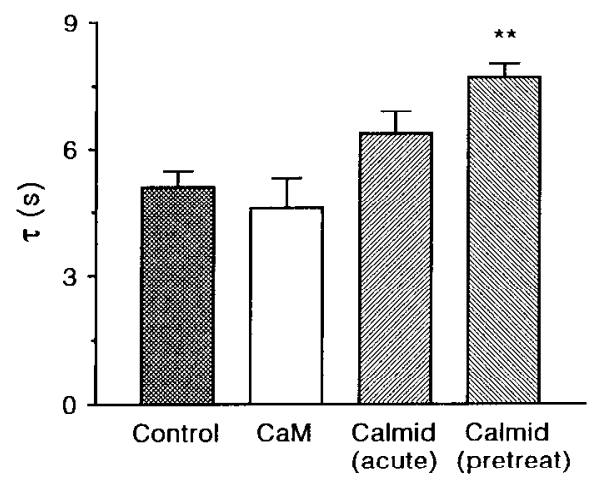

Figure 5. CaM has modest effects on $\tau$. $\left[\mathrm{Ca}^{2+}\right]_{\mathrm{i}}$ transients were recorded in whole-cell mode, and the recovery kinetics was compared (mean \pm SEM). Including CaM $(1 \mu \mathrm{M} ; n=4)$ in the patch pipette did not change $\tau$ significantly ( $4.6 \pm 0.7$ vs $5.1 \pm 0.4 \mathrm{sec}$ for control); $20 \mu \mathrm{M}$ calmidazolium [Calmid (acute); $n=4$ ] was applied via the pipette or perfusion for up to $12 \min (\tau=6.4 \pm 0.5 \mathrm{sec})$. Including calmidazolium in the bathing media for 20-35 min before recording [Calmid (pretreat)] slowed recovery kinetics significantly $(\tau=7.7 \pm 0.3 ; n=5)$. Calmidazolium was used at $20 \mu \mathrm{M}$ in all cases. ${ }^{* *} p<0.01$ versus control (Student's $t$ test).
PDBU restored $V_{\max }$ but not $K_{\mathrm{m}}$, as described previously for PMCAs in erythrocytes (Smallwood et al., 1988). When neurons were treated with the kinase inhibitor $\mathrm{H}-7$ before and during exposure to $\mathrm{PDBU}(n=5)$, the acceleration in recovery was inhibited partially, which suggests that PDBU accelerates efflux in part by activating PKC (Fig. 6C). When pretreated with $200 \mu \mathrm{M}$ H-7 $(n=5), \tau$ increased significantly over time $(p<0.001$, repeated-measures ANOVA).

\section{DISCUSSION}

This study demonstrates that in DRG neurons PMCAs are responsible for lowering $\left[\mathrm{Ca}^{21}\right]_{\mathrm{i}}$ after modest $\mathrm{Ca}^{2+}$ loads. Furthermore, PMCA-mediated $\mathrm{Ca}^{2+}$ efflux can be modulated via an autoinhibitory peptide, CaM, and the PKC-signaling pathway.

\section{PMCA removes small $\mathrm{Ca}^{2+}$ loads from the cytoplasm}

Basal $\left[\mathrm{Ca}^{2+}\right]_{i}$ levels in neurons generally are thought to be regulated by ATP-dependent pumping. Consistent with this idea are the high affinities of $\mathrm{Ca}^{2+}$ ATPases compared with other $\mathrm{Ca}^{2+}$ transport processes, as is classic work by Baker and Dipolo (1984), who reported that in dialyzed squid axon $\left[\mathrm{Ca}^{2+}\right]_{i}$ could be lowered to submicromolar concentrations by a process that required ATP and was inhibited by orthovanadate and high extracellular $\mathrm{pH}$ $\left(\mathrm{pH}_{\mathrm{o}}\right)$. In sensory neurons, vanadate and high $\mathrm{pH}_{\mathrm{o}}$ slow $\mathrm{Ca}^{2+}$ efflux (Benham et al., 1992). Schwiening et al. (1993) have recorded a $\mathrm{Ca}^{2+}$-dependent alkalinization on the surface of snail neurons that they attributed to PMCA-mediated $\mathrm{Ca}^{2+}-\mathrm{H}^{+}$exchange. Similarly, glutamate-induced alkaline shifts in the hippocampus are mediated by $\mathrm{Ca}^{2+}-\mathrm{H}^{+}$exchange (Smith et al., 1994). We have used a selective inhibitory peptide, C28R2, to show that PMCAs are the principle pathway for lowering cytoplasmic $\mathrm{Ca}^{2+}$ in DRG somata. A peptide with similar chemical characteristics, $\mathrm{G} 25$, failed to affect basal $\left[\mathrm{Ca}^{2+}\right]_{i}$ or recovery kinetics, supporting our contention that the effects of C28R2 can be attributed to inhibition of PMCA function.

The $\mathrm{Na}^{+}-\mathrm{Ca}^{2+}$ exchanger is inhibited also by C28R2 (Enyedi and Penniston, 1993) but, in the studies described here, there was no extracellular $\mathrm{Na}^{+}$, ruling out any contribution of $\mathrm{Na}^{+}-\mathrm{Ca}^{2+}$ exchange to efflux of $\mathrm{Ca}^{2+} \cdot \mathrm{Na}^{+}-\mathrm{Ca}^{2+}$ exchange might operate in reverse under our recording conditions, allowing $\mathrm{Ca}^{2+}$ to enter the cell; if this occurred, we may have underestimated slightly the 

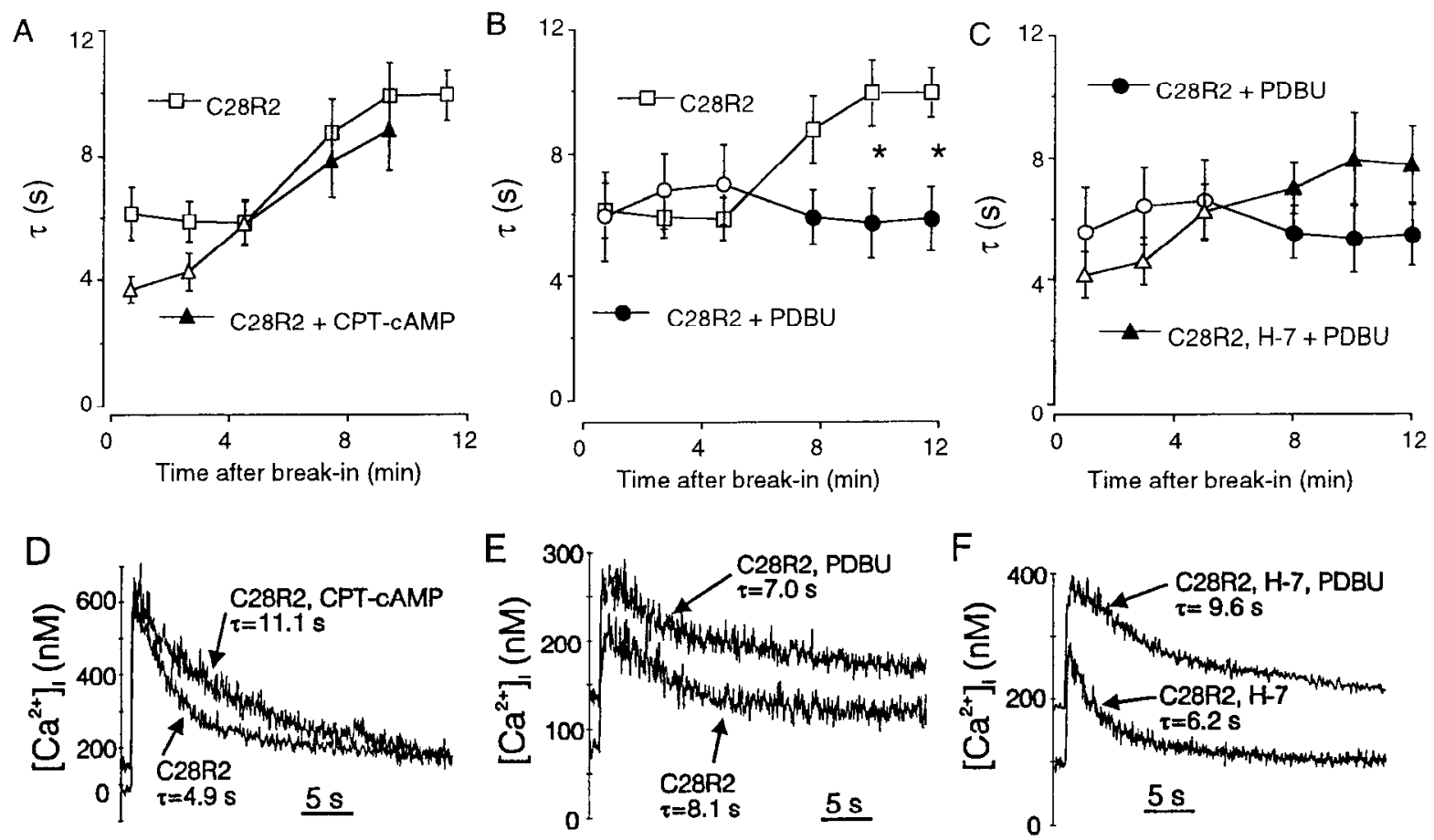

Figure 6. Modulation of PMCA by kinases. C28R2 $(10 \mu \mathrm{M})$ was included in the patch pipette for all experiments described here. Kinase activators were added to the bathing media at the time indicated by the filled symbols (after the third sweep). $A-C$, Mean $\tau\left( \pm \mathrm{SEM}\right.$ ) of recovery to basal $\left[\mathrm{Ca}^{2+}\right]_{i}$ in the presence of kinase activators. $A$, CPT-cAMP does not enhance $\mathrm{Ca}^{2+}$ efflux. $\tau$ increased significantly over time in the presence of C28R2 and $50 \mu \mathrm{M}$ CPT-cAMP $(p<0.0001$ by repeated-measures ANOVA; $n=5$ ), similar to C28R2 alone (see $\Gamma i g .4 B)$. $B$, PDBU (100 nM) prevented the slowing in $T$ normally caused by C28R2. ${ }^{*} p<0.05 \mathrm{C} 28 \mathrm{R} 2+\operatorname{PDBU}(n=4)$ versus C28R2 alone $(n=4)$ by one-way ANOVA, Bonferroni post hoc test. $C$, H-7 pretreatment partly inhibited the effect of PDBU. When pretreated with $200 \mu \mathrm{M} \mathrm{H}-7(n=5), \tau$ increased significantly over time $(p<0.001$ by repeated-measures ANOVA). $D-F$, Representative traces recorded from single neurons with C28R2 in the pipette before and after the addition of kinase activators are overlaid. $\left[\mathrm{Ca}^{2+}\right]_{i}$ transients were fitted with an exponential, and the $\tau$ for each trace is shown. $D$, $\left[\mathrm{Ca}^{2++}\right]_{i}$ transients recorded from the same cell before and after $50 \mu \mathrm{M}$ CPT-CAMP was applied to the bath. $E,\left[\mathrm{Ca}^{2+}\right]_{\mathrm{i}}$ transients recorded from the same cell before and after $100 \mathrm{nM}$ PDBU was applied to the bath. $F,\left[\mathrm{Ca}^{2+}\right]_{i}$ transients recorded from a cell that had been pretreated with $200 \mu \mathrm{M} \mathrm{H}-7$ before and after $100 \mathrm{nM}$ PDBU was applied to the bath.

contribution of PMCAs to $\mathrm{Ca}^{2+}$ efflux. In cells stimulated by electric field to elicit action potentials (physiological saline without whole-cell dialysis), recovery kinetics was similar to that studied in the whole-cell configuration $\left(\mathrm{Na}^{+}\right.$-free buffer). Thus, $\mathrm{Na}^{+}-\mathrm{Ca}^{2+}$ exchange does not play a major role in shaping $\left[\mathrm{Ca}^{2+}\right]_{\mathrm{i}}$ transients in DRG cell bodies, which is consistent with other $\left[\mathrm{Ca}^{2+}\right]_{i}$ recordings from neuronal somata (Nohmi and Kuba, 1984; Levy and Tillotson, 1988; Thayer and Miller, 1990; Benham et al., 1992).

DRG neurons possess inositol 1,4,5-trisphosphate- and caffeine-sensitive $\mathrm{Ca}^{2+}$ stores (Thayer et al., 1988a) that require SERCAs to refill, although we did not detect a $\mathrm{Ca}^{2+}$-buffering component that was sensitive to thapsigargin. Evidently, the rate of $\mathrm{Ca}^{2+}$ pumping into intracellular stores was insufficient to influence the kinetics of recovery to basal $\left[\mathrm{Ca}^{2+}\right]_{i}$ significantly, although it is possible that, after depletion, the stores contribute to $\mathrm{Ca}^{2+}$ buffering (Friel and Tsien, 1992). Sequestration of $\mathrm{Ca}^{2+}$ into thapsigargin-sensitive stores contributes to recovery from depolarization-induced $\left[\mathrm{Ca}^{2+}\right]_{\mathrm{i}}$ transients in large, but not small, DRG neurons (Schmigol et al., 1994). The cells used in the present study were of small to medium size and, therefore, would not be expected to possess a significant sequestration component to recovery kinetics. We have not addressed the contribution of $\mathrm{Ca}^{2+}$-binding proteins to shaping $\left[\mathrm{Ca}^{2+}\right]_{i}$ transients. Because the buffering properties of $\mathrm{Ca}^{2+}$-binding proteins would be expected to remain constant over the time course of our experiments, the modulation of recovery kinetics by C28R2 and PDBU strongly suggests that dissociation of $\mathrm{Ca}^{\text {? }}$ from binding sites was not the rate-limiting step in returning $\left[\mathrm{Ca}^{2+}\right]_{i}$ to basal levels.

The relative contribution of the various $\mathrm{Ca}^{2+}$-buffering processes to lowering $\left[\mathrm{Ca}^{2+}\right]_{\mathrm{i}}$ is dependent on the magnitude of the $\mathrm{Ca}^{2+}$ load. In sensory neurons, mitochondria make only a minor contribution to buffering $\mathrm{Ca}^{2+}$ at rest but exhibit robust sequestration into the matrix after large $\mathrm{Ca}^{2+}$ loads (Werth and Thayer, 1994). This study used the whole-cell patch clamp to rapidly apply small $\mathrm{Ca}^{2+}$ loads comparable with those produced by 10 action potentials. The fit of the recovery by a monoexponential and the relative insensitivity of $\tau$ to $\int I_{C \mathrm{a}}$ are consistent with a single first-order process. Kinetics of recovery was constant over the range of $\int I_{\mathrm{Ca}_{1}}$ used in this study and was in good agreement with others (Thayer and Miller, 1990; Benham et al., 1992). Thus, PMCAs appear to be the dominant mechanism for lowering $\left[\mathrm{Ca}^{2+}\right]_{i}$ at rest and during brief low-frequency activity.

\section{Modulation of PMCA-mediated $\mathrm{Ca}^{2+}$ efflux}

$\mathrm{CaM}$ activates PMCAs by interacting with a binding site near the $\mathrm{C}$ terminus. This interaction removes the tonic inhibitory influence of this region of the pump, increasing both the affinity for $\mathrm{Ca}^{2+}$ and the rate of pumping (Enyedi et al., 1991; Carafoli, 1992). The peptide we used to inhibit PMCA function, C28R2, 
represents the CaM-binding, inhibitory domain of recombinant PMCA2b. The primary effect of C28R2 is a direct interaction with the PMCA, although it also binds CaM with high affinity and thus competes with the PMCA for CaM (Enyedi et al., 1991). When included in the patch pipette, $10 \mu \mathrm{M}$ C28R2 significantly slowed the rate of $\mathrm{Ca}^{2+}$ efflux.

Benham et al. (1992) observed a slowing of $\mathrm{Ca}^{2+}$ efflux after calmidazolium treatment. Only when cells were pretreated with calmidazolium did we see a significant slowing of $\mathrm{Ca}^{2+}$ efflux. CaM may dissociate very slowly from the pump and thus require prolonged exposure to antagonist to reverse $\mathrm{CaM}$ activation. Alternatively, the PMCAs present in DRG neurons may be less sensitive to CaM than PMCAs in erythrocytes. PMCA splice variants have been described in which the CaMbinding domain was a relatively weak inhibitor of pump function. These variants have greater activity in the absence of CaM activation and are more prevalent in excitable tissues (Enyedi et al., 1994). The CaM-binding domain is also a site for proteolytic cleavage. The $\mathrm{Ca}^{2+}$-activated protease calpain will cleave the C-terminal regulatory domain of PMCAs selectively, rendering the pump insensitive to $\mathrm{CaM}$, although it remains susceptible to inhibition by exogenously added C28R2 (Salamino et al., 1994). Proteolysis may explain the need for added C28R2 to observe stimulation of pump activity, although this evidently is not attributable to the whole-cell recording conditions, because $\left[\mathrm{Ca}^{2+}\right]_{i}$ transients recorded in intact cells exhibited similar resting $\left[\mathrm{Ca}^{2+}\right]_{i}$ and recovery kinetics. Adding $\mathrm{CaM}$ to the pipette did not accelerate pump activity significantly, indicating that under our experimental conditions $\mathrm{CaM}$ has a minor influence on pump function.

Phosphorylation has been reported to influence the activity of PMCAs and SERCAs (Neyses et al., 1985; Smallwood et al., 1988). Phosphorylation by PKA of the $\mathrm{Ca}^{2+}$ pumps found in heart sarcolemma and erythrocytes enhanced $\mathrm{Ca}^{2+}$ transport by increasing the affinity of the pumps for $\mathrm{Ca}^{2+}$ (Neyses et al., 1985). We saw no enhancement of $\mathrm{Ca}^{2+}$ efflux after treatment with CPT-cAMP, an activator of cyclic nucleotide-dependent kinases. However, increasing the affinity may exert a subtle effect that would be undetected in our experiments. Alternatively, different isoforms of the PMCA may be differentially sensitive to phosphorylation by PKA. Alternative splicing of the PMCA1 gene can yield at least four different isoforms with different phosphorylation sites for cyclic nucleotide-dependent protein kinases (Strehler et al., 1989).

Smallwood et al. (1988) showed that phosphorylation by PKC stimulates the PMCA by increasing $V_{\text {max }}$. Under basal conditions, we saw no significant enhancement of $\mathrm{Ca}^{2+}$ efflux after treatment with the PKC activator PDBU. However, if C28R2 was included in the pipette, $\mathrm{PDBU}$ prevented the slowing in $\mathrm{Ca}^{2+}$ efflux normally produced by C28R2. The broad-spectrum kinase inhibitor H-7 partially inhibited the effect of PDBU. The partial effect may be attributable to the inability of $\mathrm{H}-7$ to overcome the stimulatory effect of $100 \mathrm{nM}$ PDBU coupled with the increased $\left[\mathrm{Ca}^{2+}\right]_{i}$ that was observed in these experiments. Alternatively, previous work has demonstrated that various lipids can enhance PMCA function by interacting with a lipid-binding domain (Carafoli, 1991). PDBU may interact with this lipid-binding domain of the PMCA. It is unclear why the effects of PDBU were apparent only when C28R2 was present. C28R2 may be phosphorylated directly by PKC with a subsequent decrease in efficacy (Hofmann et al., 1994), or the pump may be activated maximally under control conditions such that PDBU produces no further enhancement. Alternatively, slowing the rate of $\mathrm{Ca}^{2+}$ efflux simply may facilitate detection of the effect of PDBU.

\section{CONCLUSIONS}

In cultured rat DRG neurons, PMCA-mediated $\mathrm{Ca}^{2+}$ efflux is the process primarily responsible for recovery to basal $\left[\mathrm{Ca}^{2+}\right]_{i}$ after modest stimulation. PKC accelerates this process. Thus, PMCAs are a point of cross-talk between second-messenger systems. There are four known genes encoding PMCA isoforms, each with a number of potential splice variants (Strehler et al., 1989; Brandt et al., 1992), which suggests that PMCA variants are specialized in function, localization, and pharmacological selectivity.

Subtle changes in $\left[\mathrm{Ca}^{2+}\right]_{\mathbf{i}}$ can have profound physiological consequences. For example, $10-30 \mathrm{~nm}$ changes in $\left[\mathrm{Ca}^{2+}\right]_{\mathrm{i}}$ are capablc of cnhancing synaptic transmission twofold (Regehr et al., 1994). Similarly, variations in $\left[\mathrm{Ca}^{2+}\right]_{\mathrm{i}}$ transient duration will profoundly influence activation of $\mathrm{Ca}^{2+}$-dependent enzymes such as CaM kinase II (Hanson and Schulman, 1992). Thus, regulation of basal $\left[\mathrm{Ca}^{2+}\right]_{i}$ and $\left[\mathrm{Ca}^{2+}\right]_{i}$ transient recovery kinetics by PMCAs places these pumps in a key position for modulating $\mathrm{Ca}^{2+}$ signaling in neurons.

\section{REFERENCES}

Ahmed Z, Connor JA (1988) Calcium regulation by and buffer capacity of molluscan neurons during calcium transients. Cell Calcium 9:57-69.

Baimbridge KG, Celio MR, Rogers JH (1992) Calcium-binding proteins in the nervous system. Trends Neurosci 15:303-307.

Baker PF, Dipolo R (1984) Axonal calcium and magnesium homeostasis. Curr Top Membr Transp 22:195-247.

Belmonte C, Gallego R (1983) Membrane properties of cat sensory neurones with chemoreceptor and baroreceptor endings. J Physiol (Lond) 342:603-614.

Benlam CD, Evans ML, McBain CJ (1992) $\mathrm{Ca}^{3+}$ eflux mechanisms following depolarization evoked calcium transients in cultured rat sensory neurones. J Physiol (Lond) 455:567-583.

Brandt $P$, Neve KL, Kammesheidt A, Khoads KE, Vanaman 'IC (1992) Analysis of the tissue-specific distribution of mRNAs encoding the plasma membrane calcium-pumping ATPases and characterization of an alternatively spliced form of PMCA4 at the cDNA and genomic levels. J Biol Chem 267:4376-4385.

Carafoli F (1987) Intracellular calcium homeostasis. Annu Rev Biochem $56: 395-433$.

Carafoli E (1991) Calcium pump of the plasma membrane. Physiol Rev 71:129 153.

Carafoli E (1992) The plasma membrane calcium pump, structure, function, regulation. Biochim Biophys Acta 1101:266-267.

Choi DW (1987) lonic dependence of glutamate neurotoxicity. J Neurosci $7: 369-379$.

Enyedi A, Penniston J (1993) Autoinhibitory domains of various $\mathrm{Ca}^{2+}$ transporters cross-react. J Biol Chem 268:17120-17125.

Enyedi A, Filoteo AG, Gardos G, Penniston JT (1991) Calmodulinbinding domains from isozymes of the plasma membrane $\mathrm{Ca}^{2+}$ pump have different regulatory properties. J Biol Chem 266:8952-8956.

Enyedi A, Verma AK, Heim R, Adamo HP, Filoteo AG, Strehler EE, Penniston IT (1994) The $\mathrm{Ca}^{2+}$ affinity of the plasma membrane $\mathrm{Ca}^{2+}$ pump is controlled by alternative splicing. $\mathbf{J}$ Biol Chem 269:41-43.

Friel DD, Tsien RW (1992) A caffeine- and ryanodine-sensitive $\mathrm{Ca}^{2+}$ store in bullfrog sympathetic neurones modulates effects of $\mathrm{Ca}^{2+}$ entry on $\left[\mathrm{Ca}^{2+}\right]$. J Physiol (Lond) 450:217-246.

Friel DD, Tsien RW (1994) An FCCP-sensitive $\mathrm{Ca}^{2+}$ store in bullfrog sympathetic neurons and its participation in stimulus-evoked changes in $\left[\mathrm{Ca}^{2+}\right]_{\mathrm{i}} \mathrm{J}$ Neurosci 14:4007-4024.

Grynkiewicz G, Peonie M, Tsien RY (1985) A new generation of calcium indicators with greatly improved fluorescence properties. J Biol Chem 260:3440-3450.

Hanson PI, Schulman H (1992) Neuronal $\mathrm{Ca}^{2+} /$ calmodulin-dependent protein kinases. Annu Rev Biochem 61:559-601.

Hofmann F, Anagli J, Carafoli E, Vorherr T (1994) Phosphorylation of the calmodulin-binding domain of the plasma membrane $\mathrm{Ca}^{2+}$ pump by protein kinase $C$ reduces its interaction with calmodulin and with its pump receptor site. J Biol Chem 269:24298-24303. 
Jensen JR, Lynch G, Baudry M (1989) Allosteric activation of brain mitochondrial $\mathrm{Ca}^{2+}$ uptake by spermine and by $\mathrm{Ca}^{2+}$ : brain regional differences. J Neurochem 53:1182-1187.

Levy S, Tillotson $\mathrm{D}$ (1988) Effects of $\mathrm{Na}^{\prime}$ and $\mathrm{Ca}^{2+}$ gradients on intracellular free $\mathrm{Ca}^{2+}$ in voltage-clamped Aplysia neurons. Brain Res 474:333-342.

Lo T-M, Thayer SA (1993) Refilling the inositol 1,4,5-trisphosphatesensitive $\mathrm{Ca}^{2+}$ store in neuroblastoma $\times$ glioma hybrid NG108-15 cells. Am J Physiol 264:C641-C653.

Luther PW, Yip RK, Bloch RJ, Ambesi A, Lindenmayer GE, Blaustein MP (1992) Presynaptic localization of sodium/calcium exchangers in neuromuscular preparations. J Neurosci 12:4898-49(04.

Miller RJ (1988) Calcium signalling in neurons. Trends Neurosci $11: 415-419$.

Miller RJ (1991) The control of neuronal $\mathrm{Ca}^{2+}$ homeostasis. Prog Neurobiol 37:255-285.

Neyses L, Reinlib L, Carafoli E (1985) Phosphorylation of the $\mathrm{Ca}^{2+}$ pumping ATPase of heart sarcolemma and erythrocyte plasma membrane by the cAMP-dependent protein kinase. J Biol Chem 260:10283-10287.

Nohmi M, Kuba K (1984) Effects of $\mathrm{Na}^{\prime}$ gradient on the intracellular $\mathrm{Ca}^{2+}$ oscillation in the sympathetic ganglion cell: $\mathrm{Na}-\mathrm{Ca}$ exchange in the neurone cell soma? Brain Res 324:171-174.

Randall RD, Thayer SA (1992) Glutamate-induced calcium transient triggers delayed calcium overload and neurotoxicity in rat hippocampal neurons. J Neurosci 12:1882-1895.

Regehr WG, Delaney KR, Tank DW (1994) The role of presynaptic calcium in short-term enhancement at the hippocampal mossy fiber synapse. J Neurosci 14:523-537.

Salamino F, Sparatore B, Melloni E, Michetti M, Viotti PL, Pontremoli S, Carafoli E (1994) The plasma membrane calcium pump is the preferred calpain substrate within the erythrocyte. Cell Calcium 15:28-35.

Schwiening CJ, Kennedy HJ, Thomas RC (1993) Calcium hydrogen exchange by the plasma membrane Ca-ATPase of voltage-clamped snail neurons. Proc R Soc Lond [Biol] 253:285-289.
Shmigol A, Kostyuk P, Verkhratsky A (1994) Rolc of caffeinc-sensitive $\mathrm{Ca}^{2+}$ stores in $\mathrm{Ca}^{2+}$ signal termination in adult mouse DRG neurones. NeuroReport 5:2073-2076.

Sipahimalani AS, Werth JL, Michelson KH, Dutta AK, Efange SMN, Thayer SA (1992) Lipophilic amino alcohols with calcium channel blocking activity. Biochem Pharmacol 44:2039-2046.

Smallwood JI, Gugi B, Rasmussen H (1988) Regulation of erythrocyte $\mathrm{Ca}^{2+}$ pump activity by protein kinase C. J Biol Chem 263:2195-2202.

Smith S, Gottfried J, Chen J, Chesler M (1994) Calcium dependence of glutamate receptor-evoked alkaline shifts in hippocampus. NeuroRe port 5:2441-2445.

Strehler EE, Strehler-Page M, Vogel G, Carafoli E (1989) mRNAs for plasma membrane calcium pump isoforms differing in their regulatory domain are generated by alternative splicing that involves two internal donor sites in a single exon. Proc Natl Acad Sci USA 86:6908-6912

Thayer SA, Miller R.J (1990) Regulation of the free intracellular calcium concentration in rat dorsal root ganglion neurones in vitro. J Physiol (Lond) 425:85-115.

Thayer SA, Perncy TM, Miller RJ (1988a) Regulation of calcium homeostasis in sensory neurons by bradykinin. J Neurosci 8:4089-4097.

Thayer SA, Sturek M, Miller RJ (1988b) Measurement of neuronal $\mathrm{Ca}^{2+}$ transients using simultaneous microfluorimetry and electrophysiology. Pflügers Arch 412:216-223.

Thomas D, Hanley MR (1994) Pharmacological tools for perturbing intracellular calcium storage. Methods Cell Biol 40:65-89.

Tsien RW, Tsien RY (1990) Calcium channels, stores and oscillations. Annu Rev Cell Biol 6:715-760.

Werth JL, Thayer SA (1994) Mitochondria buffer physiological calcium loads in cultured rat dorsal root ganglion neurons. J Neurosci $14: 348-356$.

Werth JL, Zhou B, Nutter LM, Thayer SA (1994) 2',3'-Dideoxycytidine alters calcium buffering in cultured dorsal root ganglion neurons. Mol Pharmacol 45:1119-1124. 